\title{
The death of ink: the value of typing skills as an addition to the medical school curriculum
}

\author{
Saiful Miah' \\ Hashim U Ahmed ${ }^{2}$ \\ 'Department of Urology, Imperial \\ College Healthcare NHS Trust, \\ Charing Cross Hospital, ${ }^{2}$ Imperial \\ College London, London, UK
}

This article was published in the following Dove Press journal:

Advances in Medical Education and Practice

5 October 2017

Number of times this article has been viewed

\section{Dear editor}

We read with great interest the article by Malik on the importance of writing skills, which has been highlighted as one of the four competencies that all medical students should possess as future doctors. ${ }^{1}$ Malik's article also stated that "first and foremost" writing in a legible manner is imperative for good clinical practice. ${ }^{1}$

While we wholeheartedly agree with these statements, one potentially overlooked skill that we predict will overtake the requirement of legible writing skills within a generation of doctors is typing proficiency. Decades of investment and development of electronic health records (EHRs) have resulted in a greater implementation of this tool globally. ${ }^{2}$ EHRs have been shown through use of reminders, electronic order sets and other means to improve reliability of performance of many basic tasks in acute, preventive and chronic medical care. ${ }^{2}$

Optimal utilization of EHRs requires sound typing skills. There is evidence that the majority of newly qualified doctors lack this skill, which could potentially impact on their time for learning as well as patient care. ${ }^{3}$ We are in agreement with Malik that a greater emphasis is required for medical students to develop their writing skills in the undergraduate curriculum. We would also propose formal typing skills and increased familiarity with EHR systems to be introduced in the medical curricula. This would be in-keeping with the evolution of contemporary medical practice, which is resulting in the slow "death of ink" as medium of communication and documentation.

\section{Disclosure}

The authors report no conflicts of interest in this communication.

\section{References}

1. Malik B. The value of writing skills as an addition to the medical school curriculum. Adv Med Educ Pract. 2017;8:525-526.

2. Payne TH. The electronic health record as a catalyst for quality improvement in patient care. Heart. Epub 2016 Aug 8. doi: 10.1136/heartjnl-2015-308724.

3. Kalava A, Ravindranath S, Bronshteyn I, Munjal RS, Schianodicola J, Yarmush JM. Typing skills of physicians in training. J Grad Med Educ. 2014;6(1):155-157.
W6 8RF, UK

Email saiful.miah@ucl.ac.uk 
Dove Medical Press encourages responsible, free and frank academic debate. The content of the Advances in Medical Education and Practice 'letters to the editor' section does not necessarily represent the views of Dove Medical Press, its officers, agents, employees, related entities or the Advances in Medical Education and Practice editors. While all reasonable steps have been taken to confirm the content of each letter, Dove Medical Press accepts no liability in respect of the content of any letter, nor is it responsible for the content and accuracy of any letter to the editor.

Advances in Medical Education and Practice

Dovepress

\section{Publish your work in this journal}

Advances in Medical Education and Practice is an international, peerreviewed, open access journal that aims to present and publish research on Medical Education covering medical, dental, nursing and allied health care professional education. The journal covers undergraduate education, postgraduate training and continuing medical education research, and health care services. The manuscript management system is completely online and includes a very quick and fair peer-review system. Visit http://www.dovepress.com/testimonials.php to read real quotes from published authors.

Submit your manuscript here: http://www.dovepress.com/advances-in-medical-education-and-practice-journa 